Revue d'études américaines. American Studies Journal

$2 \mid 2017$

(Hi)stories of American Women: Writings and Rewritings / Call and Answer: Dialoguing the American West in France

\title{
Impressionist Art in Private Clubs: The Case Study of the Union League Club (1886-1902)
}

\section{Claire Hendren}

\section{(2) OpenEdition \\ Journals}

\section{Electronic version}

URL: https://journals.openedition.org/transatlantica/10610

DOI: 10.4000/transatlantica.10610

ISSN: $1765-2766$

Publisher

Association française d'Etudes Américaines (AFEA)

\section{Electronic reference}

Claire Hendren, "Impressionist Art in Private Clubs: The Case Study of the Union League Club (1886-1902)", Transatlantica [Online], 2 | 2017, Online since 13 May 2019, connection on 02 February 2023. URL: http://journals.openedition.org/transatlantica/10610 ; DOI: https://doi.org/10.4000/ transatlantica. 10610

This text was automatically generated on 2 February 2023

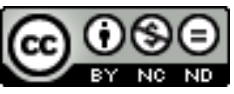

Creative Commons - Attribution-NonCommercial-NoDerivatives 4.0 International - CC BY-NC-ND 4.0 https://creativecommons.org/licenses/by-nc-nd/4.0/ 


\title{
Impressionist Art in Private Clubs: The Case Study of the Union League Club (1886-1902)
}

\author{
Claire Hendren
}

\section{Introduction}

Clubs absorb so much of the vitality of the community at the present time that they owe a proportionate return. The most successful clubs avoid the stagnation of selfculture by various aids to municipal life. The Union League, the Lotus, the Grolier Clubs in New York, among others, do work for art culture of the greatest importance in their special exhibitions. (Walker 7)

Clubs were vital institutions during the Gilded Age in the United States, politically but also artistically and culturally, as pointed out here in this 1896 article from the Independent. Private clubs proliferated in the last decades of the nineteenth century thanks to the unprecedented wealth brought by industrialization and the end of the Civil War. In 1873, New York City boasted over one hundred social clubs, more than any other urban area (Fairfield 7). The 1890s saw extraordinary growth in club memberships and by 1903, 60,000 men owned memberships to New York City clubs (Becker 15). Although the Union League Club's ambitions were political, the arts played an important part in their national agenda. Art exhibitions and talks became essential components for clubs nationwide and impacted the development of a distinctly American artistic taste at the turn of the twentieth century.

2 French Impressionism's reception in American clubs serves as a valuable case study to better understand how these social institutions were instrumental in fostering positive reactions towards controversial art movements. Whereas in France positive reactions towards Impressionism came from the dealer-critic system (White and White 1993), in the United States one needs to turn to clubs to understand how Impressionism became popular in the late 1880 s and early 1890 s. Clubs, as culturally vital associations, helped sway Americans' opinions and urged the broader population to consider Impressionism 
as a valid artform. Although the example of Boston's St. Botolph Club has already been studied (Birmingham), New York City's Union League Club has been largely underexamined. ${ }^{1}$ As an attempt to better understand the importance of clubs in the development of an American artistic taste more broadly, this paper considers New York's Union League Club's early appreciation of Impressionism perceptible in exhibition catalogues and contemporaneous press articles, so as to assess its repercussion on a broader audience.

\section{The Union League Club: Politically Engaged for the Arts}

3 Unlike European clubs, American clubs were instrumental in propagating social, cultural and political values at the same time (Smith 16). While all New York clubs had social, cultural and political goals, each institution had a particular focus: the Harmonie, the Union, the Travelers, or the New York Athletic clubs were social; the Century, the Lotos, the Salmagundi or Tile clubs were cultural; and the Union League, the Manhattan or the American clubs were political (Skalet 73). Despite being one of the most political clubs in the United States, the Union League Club leant towards the social and cultural much more than its English counterparts (Becker 15).

4 Founded during the Civil War by the leaders of the pro-Union Sanitary Commission as a patriotic institution whose purpose was to help Union troops fight the Confederates, (Irwin et al. 10-13), the Union League Club raised money to recruit regiments of AfricanAmerican troops ("New York Gossip," 1876 5). The association also showed strong loyalty towards a Republican ideology. The club strived to "elevate and uphold faith in Republican government, to dignify politics as a pursuit in faith in Republican government" (Irwin et al. 13). Its members, including Henry Whitney Bellows, the president of the United States Sanitary Commission, Frederick Law Olmsted, the designer of Central Park, and John Taylor Johnston, the president of the Central Railroad of New Jersey, were mostly part of the governing class (Ayres 15-16). Hudson River school painter Albert Bierstadt was among the few artists to belong to the club (Moore 216-222). The club expanded to Boston, Brooklyn, Chicago, Philadelphia, and Pittsburgh although none of the sister institutions became as influential nationwide as the original. At the end of the Civil War, New York's Union League Club continued its efforts with civic and cultural causes-it contributed to founding the American Museum of Natural History, the New York City Fire Department and to securing funds for the base of the Statue of Liberty. With members belonging to the political and industrial elite, the club remained a highly respectable institution long after its implication in the Civil War. 


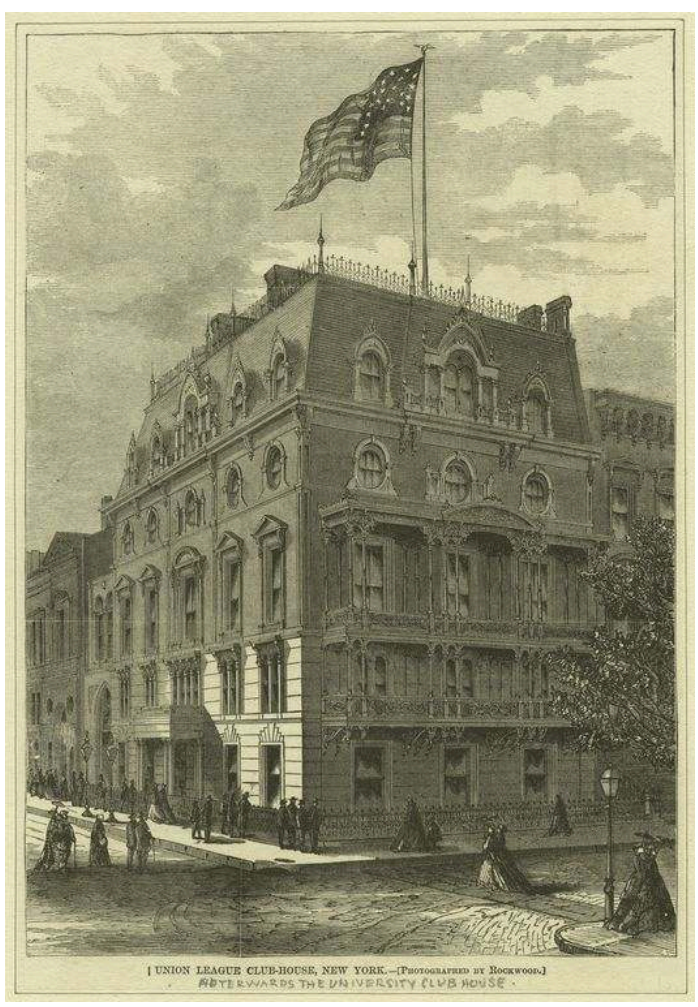

5 Unprecedented cultural growth during the Gilded Age impacted all clubs, including the most political. The United States entered the art market during the second half of the nineteenth century. Starting in the 1840s and the 1850s, New York rose as a cultural capital, eclipsing Philadelphia and Boston, the long-standing incumbents (Smith 62). Between 1885 and 1895, New York became the dominant place for art exchange in the United States (Smith 9). In the 1870s, Americans pivoted from buying primarily American art to being one of the strongest markets for European artworks (Gerdts 21). In addition to its signaling of status for private collectors, art conveyed a moral mission -that of tempering materialism-and a political one-it signaled that a Republic could foster arts and culture (Miller viii, 21).

Despite the Union League Club's political aspirations, critics regarded it as one of the finest in New York City when it came to the arts. As an 1887 New York Times critic claimed, "the course of the committee at the Union League secures only works of merit for their monthly exhibitions" ("Pictures Shows at Clubs" 7). The Union League Club's first art exhibition took place in February 1867 (Fairfield 175). When the club moved to new headquarters in April 1868, increased space provided an actual art gallery and helped exhibitions become more ambitious. Nine art exhibitions started to be held per year in the late 1870s. Beginning in 1879, the exhibitions remained open to invited guests, not just members, for an additional ten days (Skalet 88-90). By March 1881, the club moved again, this time, to grander headquarters on Fifth Avenue at the corner of Thirty-Ninth Street, which facilitated large-scale exhibitions (The Union League Club of New York, 1891 2)

7 As Linda Henefield Skalet notes, "it had been the intention of the founders of the club to include among its members not only the political leaders of New York but also the leaders in the arts and letters in order to ensure the survival of their organization beyond the end of the war" (Skalet 85). The club's involvement in the foundation of the Metropolitan Museum of Art further illustrates the combination of cultural interest 
and political agenda that characterized it. It was Union League Club member John Jay, son of a founding father and United States minister to Austria, who suggested the foundation of a national museum. The idea for such an institution came about during an 1866 Fourth of July dinner at the Pré Catelan in Paris held to commemorate American Independence's ninetieth anniversary (Tomkins 28). The men gathered on the occasion decided that the United States needed a national gallery comparable to the Musée du Louvre in Paris or the National Gallery in London. Upon his return, Jay, newly elected president of the Union League Club, encouraged the establishment of the Metropolitan Museum of Art (Note, 1871, 1-2). Members met at the Union League Club in 1869, and the Metropolitan Museum of Art was incorporated in 1871 (Bolas 12). Although the club's goals remained more political than artistic, its exhibits also showcased a desire to be innovative in the arts, which in turn served the political agenda of turning the United States into a leading nation on all fronts.

\section{French Impressionism at the Union League Club}

The first official French Impressionist exhibition in the United States opened at New York City's American Art Association in April 1886 when James Sutton, a founder of the institution, and Paul Durand-Ruel, an art dealer who lent the artworks, coordinated to introduce Impressionism to the American people. 1886 was undeniably a decisive year for the Impressionists; their last group exhibit took place in Paris and introduced an era of increased recognition in France. Prior to the first exclusively impressionist exhibit in the United States in 1886, select paintings had been included in earlier American shows: collector Louisine Havemeyer loaned Edgar Degas' A Ballet (1876; The Nelson-Atkins Museum of Art) to the 1878 American Watercolor Society exhibit; Durand-Ruel lent several pictures to the Official Foreign Manufacturer Fair in Boston in 1883; the same year the Pedestal Fund Exhibition in New York also included works by Degas and Edouard Manet. European and French dealers catered to the self-made American industrialists by developing aggressive marketing strategies such as auction sales, one-man shows and exhibition catalogues (Burns 59; Harris 57; Ott 133-141). These commercial practices did not go unnoticed in the press: Alfred Trumble noted in 1889 that "at any rate, the works of this special artistic cult recur with constantly increasing frequency in our sales and dealers' galleries, and the fact that they are imported, under our tariff, proves that there must be a commercial reason for importing them" (Trumble 11). Following the success of these inaugural endeavors, Durand-Ruel and his sons opened their initial New York City gallery in 1887 (Thompson 107-120).

9 As early as October $27^{\text {th }}, 1886$, the Union League Club included French Impressionist paintings in one of its events. The club hosted a reception for the French government's delegates visiting New York City for the Statue of Liberty's inauguration and showcased two impressionist paintings in its art selection. Manet's The Bullfight (1865-1866; Chicago Art Institute) and Claude Monet's Mail Post at Étretat (unidentifiable) adorned the club's walls alongside other more conservative examples. Although journalists did not comment on the Impressionist paintings, the works' inclusion underlines the Union League Club's intention to promote modern art. The Impressionists were debated at the time in the United States, ${ }^{2}$ which renders the decision to hang two impressionist paintings during a prestigious political event more significant still. 

Monet's first one-man show in the United States. A selection of forty-seven old master paintings and thirty-four by Monet made up the Exhibition of Old Masters and American and Foreign Artists Along with an Exhibition by Monet the Impressionist. Pictures by Frank Hals as well as paintings by the much-coveted Barbizon school hung in rooms adjacent to Monet's works. Dealers, especially Durand-Ruel, used the strategy of hanging esteemed painters together with avant-garde artists so that "respectable artists g[ive] an aura of respectability to their groups of impressionist works" (Weitzenhoffer 84). By putting Impressionism on the same footing as works by well-established artists, the selection committee intended to sway the viewers' opinions in favor of Impressionism (Pyne 226).

11 The art on view belonged to American collectors, including Alfred Atmore Pope, William Fuller, Erwin Davis, Alfred Kingman, James Sutton and Albert Spencer (who lent anonymously), as well as dealers Durand-Ruel and Boussod, Valadon \& Cie (Exhibition catalogue, 1891). This shared provenance of the works highlights two intentions. Seeing the names of respected individuals as the owners of controversial art might help other club members consider the artwork more seriously. ${ }^{3}$ Many of the lenders were also club members and the common membership between viewer and owner vouched for shared values. Additionally, the fact that dealers lent art suggests the hopes of selling. The Union League Club exhibits, like many other club shows, offered not only the opportunity to view art, but also to purchase it.

As members of the art committee New York City collectors, dealers, and experts made the selections for the exhibitions. They arranged loans with local collectors and encouraged the club's turn towards more experimental art. In 1891, when the club hosted its first Monet exhibition, Thomas B. Clarke, a businessman in the linen industry turned art dealer and advisor in 1888, chaired the art committee. Through his own purchases and those for his advisees, he became acquainted with recent developments in European art and New-York based European art collections, which enabled him in turn to put on such shows for the club. Art dealer Samuel P. Avery, who owned several impressionist prints that he later gifted to the New York Public Library also served on the committee. Alongside its more liberal political leanings, the Union League Club was known for its more liberal acceptance of upcoming styles than other New York clubs such as the Century (Skalet 87, 93). It should be noted however that modern, industrialized France, the subject of many impressionist paintings, resonated with the industrialist patrons who loaned and organized exhibits as they themselves were shaping an industrialized society in the United States (Broude 32). 


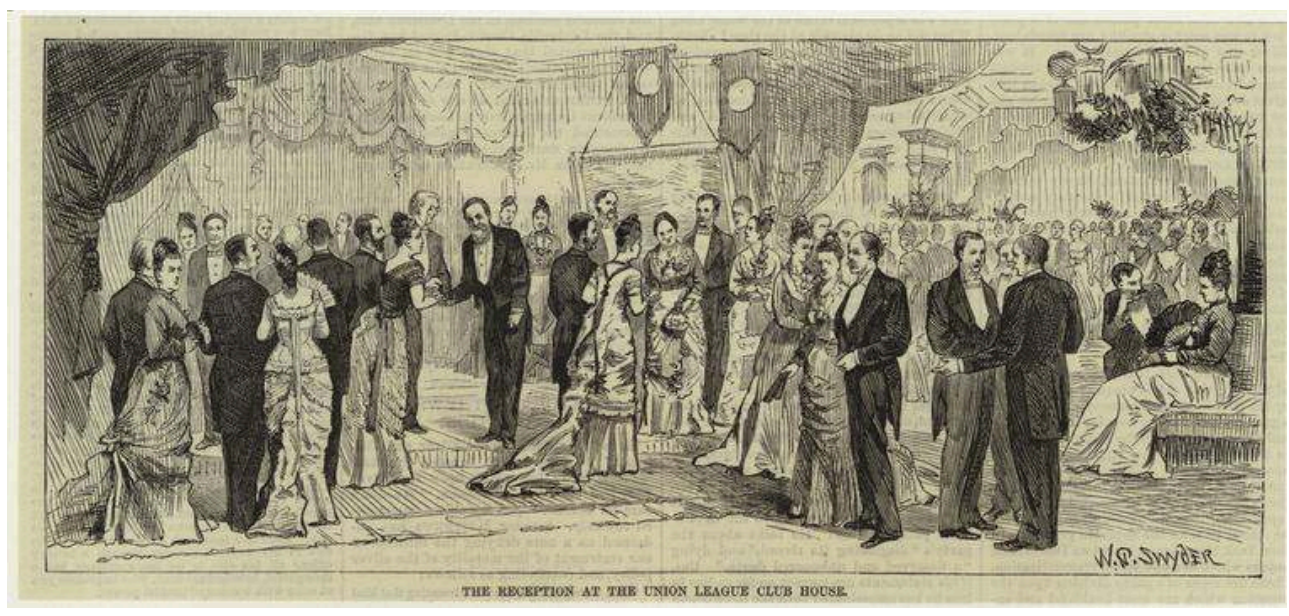

13 The first large-scale impressionist club exhibition gathered enough praise for the Union League Club to plan others. In February 1899, the club organized a Monet exhibition along with more conservative painter Paul-Albert Besnard. Twenty-one pictures made up the show, thirteen of which were by Monet, eight by Besnard, and two were sculptures by Auguste Rodin. In November 1902, the Union League Club held another exhibit of Paintings by Modern European Masters, with thirty pictures by Monet, Camille Pissarro and Alfred Sisley loaned by New York dealers Knoedler, Durand-Ruel, Glaenzer, and Oehme.

\section{Influence of The Union League Club}

14 The Union League Club helped popularize French Impressionism. By including impressionist paintings in its shows, the club conclusively enhanced the credibility of an artistic movement that remained controversial. The press also did its share by mentioning the exhibitions to national readers in increasingly praiseful articles. This way, a broader audience became acquainted with Impressionism. As Frank Luther Mott explained, based on an 1892 survey, American periodicals had an "almost incalculable influence upon the moral and intellectual development of individuals, upon home life, and upon public opinion" (14). Even if Monet's work failed to convince all journalists in the late 1880 s and early 1890s, the Union League Club and its prestige encouraged critics from national publications such as the New York Times to discuss the exhibitions. Thanks to the club's repute, national newspapers became interested in a controversial painter and increased the artist's audience. The club's sphere of influence and frequent French Impressionist exhibitions fostered a positive attitude towards the French school. Whereas in France positive reactions towards Impressionism came from the dealer-critic system (White and White 1993), the same system alone did not shape American reception. Clubs helped to sway Americans' opinions and urged the broader population to consider Impressionism as an art.

15 At the 1891 exhibit for example, most American critics preferred George Inness' paintings ("Pictures at the Union League," 1891 4). Several critics, however, wrote neutral if not positive reviews on impressionist oeuvres. A journalist from The Critic revealed his uncertainty towards Monet when he claimed that, "the Monets [...] gained by the size of the room, and by the artificial light which supplied the yellow tones that they lack" ("Paintings at the Union League," 1891 101). Although the review was mixed, 
the critic finished his article by saying that "perhaps no other way of working than his could so well reproduce the confusion of rocks and vegetation in "Mountains of the Creuse"" ("Paintings at the Union League" 101). Likewise, the journalist from The Art Amateur suggested that the "rather favorable" exhibition conditions at the Union League Club "put an end to all reasonable doubt about this painter's position in contemporary art" ("Union League Club Exhibition," 1891 89), a mixed praise which implied that the exhibition conditions as much as the quality of Monet's works led to the commendation of his art.

The Union League Club therefore fabricated an aura of respectability that encouraged critics to consider the paintings more seriously. As a journalist of the Washington Post commented regarding the first official showing of the Impressionists at the American Art Association in April 1886, "the press of New York is in a painful state of indecision as the correct opinion for the most part to which the only exceptions take refuge in the safety of ridicule" ("The Paintings of the Impressionists" 4). However, when the Union League Club exhibited paintings by one of the leading artists of the movement only five years later, the artwork had gained in credibility. By the 1902 exhibit, all comments were positive. One journalist even complained that the center walls showcased academic painters Jules Lefebvre, Jules Breton and William-Adolphe Bouguereau who had "almost nothing to recommend it to serious attention" while Sisley's works "equal[ed] the best he ever painted" (Van Oost 3).

The selection made by the members of the committee also better responded to Americans' aspirations. The Hudson River School had established a strong landscape tradition in the country; in addition, a residue of American puritanism tended to discourage nudity and scenes deemed immoral. An 1886 article from The Critic pointed to a preference for impressionist landscapes by asserting that "the tenderness and grace of Impressionism are reserved for its landscapes: for humanity there is only the hard brutality of the naked truth." ("The French Impressionists" 196). True enough, the Union League Club's committee showcased Monet landscapes, not Pierre-Auguste Renoir's figure paintings which were less likely to encourage the movement's acceptance.

18 It was not only through the press that the Union League Club's influence transpired; other institutions followed the Club's lead in including Impressionist works in exhibits. In March 1893, the American Fine Arts Society held a Loan Exhibition to raise money for the society's building for which dealers Durand-Ruel and Boussod, Valadon \& Cie. loaned most of the selection. Journalist Susan Hayes Ward mentioned that the west side of the exhibition showed exclusively impressionist paintings with "half a dozen" examples (Ward 7) and a writer from The Critic noted that, "many of the pictures have already been exhibited at the Union League Club" ("The Fine Arts" 103). Tracing an exact piece that was exhibited in both the Union League Club's 1891 show and the Fine Arts Society's 1893 Loan Exhibition remains difficult: the club's exhibitions came primarily from private collections while the loan exhibition came exclusively from dealers, and vague titles make works hard to trace. However, the Union League Club's reputation and the popularity of its art shows most likely encouraged the organizers of the 1893 fundraiser exhibit to include impressionist paintings. Such transfers tend to suggest that the sphere of influence of the elite helped Impressionism become prevalent outside their own club. 


\section{Competition Amongst Clubs}

The most noticeable and we may say the most encouraging aspect of the enlargement of social opportunity and experience which is going on around us now is the rapid growth both in numbers and size of our clubs and the almost universal demand they are making for better facilities and accommodations (Lotos Club Member book, cited in Becker 16).

19 As clubs became more common, each institution tried to distinguish itself from another. The reputations of the various institutions relied heavily on their art exhibitions. As Doris Birmingham highlighted in her study of Boston's St. Botolph Club, clubs other than the Union League Club hosted impressionist exhibitions early on. However, the New York City institution and Boston's St. Botolph Club's goals differed widely. While the Union League Club counted many members of the political class, the St. Botolph Club focused on cultural endeavors. ${ }^{4}$ Academics such as Thomas Sergeant Perry and artists such as Joseph Foxcroft Cole actively participated in the association. The club houses' extravagance-or lack thereof-illustrates the institutions' diverging missions. The St. Botolph Club offered "simple and inexpensive suppers" (cited in Birmingham 26) whereas the Union League Club added an additional dining room, the "alcove dining room," in 1881 for private parties ("A Club Dining-Room" 125).

Despite their different aims, both clubs exhibited impressionist works and took pride in doing so. The St. Botolph Club held impressionist exhibits in March 1892, February 1895, 1899 and 1905. Local collector Desmond Fitzgerald, who wrote the exhibition catalogue's preface to the 1892 show entirely devoted to Monet, claimed that the showing was the country's first dedicated to Monet and that "as such, [it] may become a notable art event" ("An Exhibition of Paintings by Claude Monet," 1892 2). This erroneous assertion highlights Fitzgerald's eagerness to assert the St. Botolph Club's prevalence at the expense of the New York Union League Club. It also underscores the rivalry amongst cities and clubs in the fabrication of an American taste. As these cities fought for cultural supremacy, club members also took part in the competition and sought to have their city and their club recognized as the most refined and artistically relevant.

21 Similarly, the Lotos Club of New York held a Monet exhibition in January 1899 at the same time when the Union League included French Impressionist art in its monthly exhibit. A New York Times journalist commented that, "the Monets shown are a supplement to the Lotos Club display, and, although they evidence again the artist's remarkable versatility, do not give, as a whole, as complete or good an idea of his ability as did the exhibition at the Lotos Club" ("Art at the Union League" 4). The critic's comments highlight the competition that existed among clubs in the same city. The statement further reveals that other clubs promoted the same artist and that Impressionism became so popular that two clubs organized impressionist exhibits during the same month. The Union League Club, with its early impressionist exhibits in the United States, therefore played an instrumental role in introducing Impressionism to the country. In turn, with the movement's growing popularity in the 1890s thanks to dealers' marketing strategies and the Union League Club's inclusion of the movement, Impressionism became widespread in other clubs.

As Skalet has underlined, "one important characteristic shared by the majority of the membership was the desire to be recognized as connoisseurs. A familiarity with the arts was, like memberships in the exclusive gentlemen's clubs, one of the aspirations of 
New York's wealthy men" (73). Being able to recognize new artists was perhaps the best proof of artistic knowledge, as one was able to rely on personal judgment to go beyond established traditions. The fact that many of the paintings lent to club exhibitions came from its members' collections only makes Skalet's statement stronger. Impressionism helped turn the clubs that supported it into trendsetters-a goal they were eager to take.

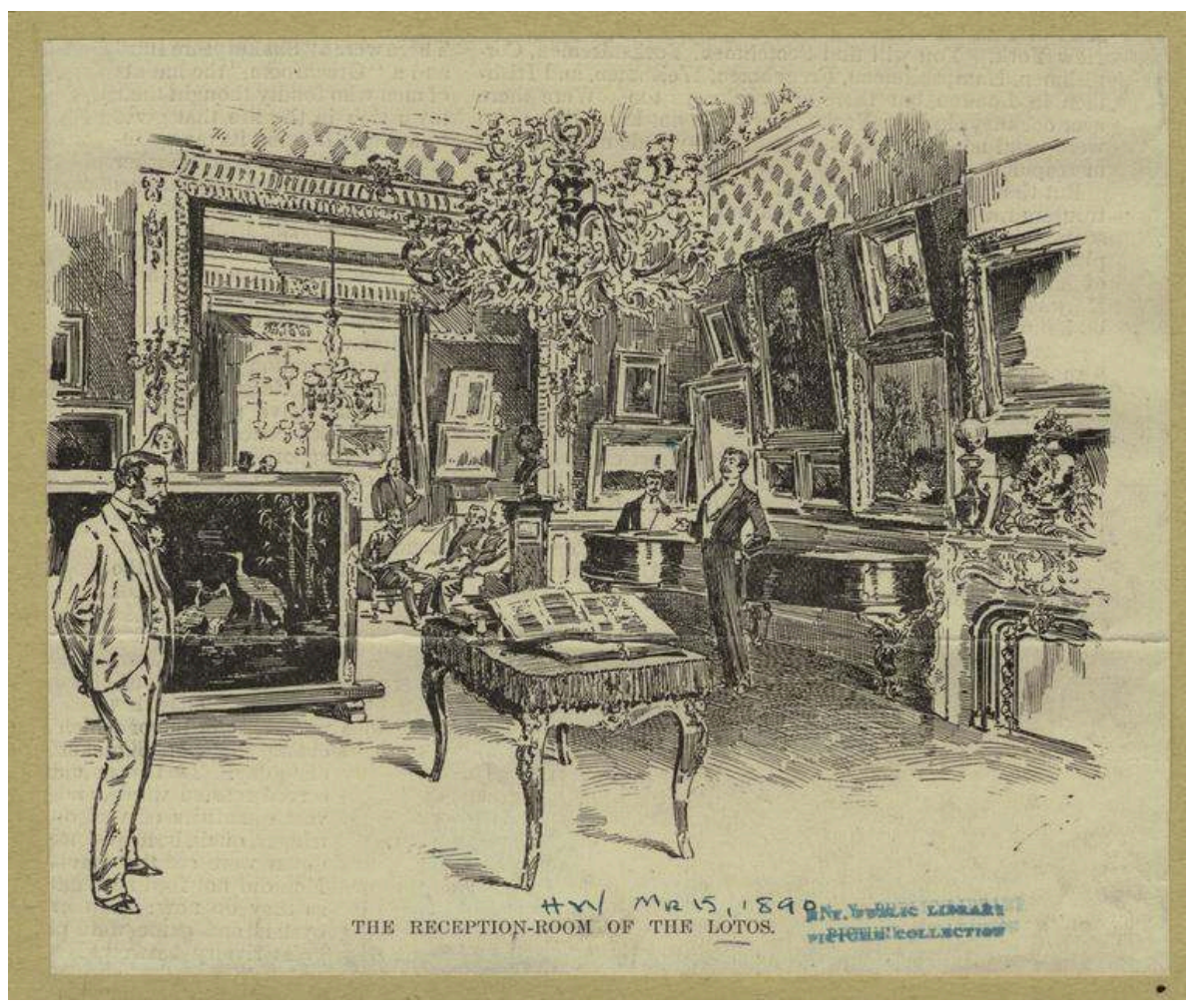

Through frequent exhibitions, sometimes monographic, Americans regularly saw and read about Impressionist works of art through the late nineteenth century. The Union League Club, one of the nation's most renowned clubs, fostered a broad appreciation for, and acceptance of, Impressionism nationwide thanks to its respectable reputation and influential collectors. Eagerness to show refined taste in art also urged the club members to adopt the controversial art school early on. After 1902, the Union League Club continued to show impressionist paintings, as the March 1913 exhibition Paintings by Various Schools illustrates, but by then, French Impressionists had become masters of the modern school.

While actors including collectors, critics, and American artists trained abroad have long been considered as tastemakers in the United States, the vital role clubs played at the time has benefited from less attention. As early as 1886, the art critic Montezuma highlighted how impactful clubs were: "By such means, thousands of persons, presumably educated, but who, if the truth were known, could not tell a water-color drawing from an oil painting, or an etching from a woodcut, are almost unconsciously taught, in an agreeable manner, the alphabet of the graphic arts, and by and by, no longer content simply to 'know what they like' [...] are able to tell you why they like it." (Montezuma 28). The Union League Club's acceptance and inclusion of a oncecontroversial European school thus offers a productive case study that helps us better appreciate the evolution of an American artistic taste and connoisseurship at the turn of the twentieth century. 


\section{BIBLIOGRAPHY}

Works Cited

“A Club Dining-Room.” The Art Amateur, vol. 4, no. 6, May 1881, 125.

“An Exhibition of Paintings by Claude Monet." Exhibition catalogue. St. Botolph Club, Boston, March 28-April 9, 1892, Boston: St. Botolph Club, 1892.

“Art at the Union League." New York Times, February 10, 1899, p. 4.

AYRES, William S. The Domestic Museum in Manhattan: Major Private Art Installations in New York City, 1870-1920. 1993. University of Delaware. PhD dissertation.

BECKER, Jack. A Taste for Landscape: Studies in American Tonalism. 2002. University of Delaware. PhD dissertation.

BELLOWS, Henry H. Historical Sketch of the Union League Club: Its Origin, Organization and Work, 1869-1873. New York: G.P. Putnam's sons, 1879.

BIRMINGHAM, Doris A. “Boston's St. Botolph Club: Home of the Impressionists.” Archives of American Art Journal, vol. 31, no. 3, 1991, p. 26-34.

BOLAS, Gerald D. The Early Years of the American Art Association, 1879-1900. 1998. The City University of New York. PhD dissertation.

BRENNECKE, Nancy M. “The Painter-in-Chief of Ugliness": Edouard Manet and Nineteenth-Century America. 2001. The City University of New York. PhD dissertation.

BROUDE, Norma, editor. World Impressionism: The International Movement, 1860-1920. New York: H.N. Abrams, 1990.

BURNS, Sarah. Inventing the Modern Artists, Art and Culture in Gilded Age America. New Haven: Yale University Press, 1996.

DAWSON, Anne. "Idol of the Moderns": Renoir's Critical Reception in America 1904-1940. 1996. Brown University. PhD dissertation.

"Exhibition of Paintings by Old Masters, and Modern Foreign and American Artists, Together with an Exhibition of the Work of Monet the Impressionist." Exhibition catalogue. The Union League Club, New York, February 12-14, 1891. New York: The Union League Club, 1891.

FAIRFIELD, Francis Gerry. The Clubs of New York. New York: Henry L. Hinton, 1873.

FIDELL-BEAUFORT, Madeleine, and Jeanne K WELCHER. "Some Views of Art Buying in New York in the 1870s and the 1880s." Oxford Art Journal, vol. 5, no. 1, 1982, p. 48-55.

GARCZYNSKI, Edward R. “Jugglery in Art.” Forum, August 1886, p. 592-603.

GERDTS, William H., editor. American Impressionism. New York: Abbeville Press, 1980.

HARRIS, Neil. Cultural Excursions: Marketing Appetites and Cultural Tastes in Modern America. Chicago: University of Chicago Press, 1990.

HART, Charles H. "Fine Arts: The Pennsylvania Academy Exhibition." The Independent, March 5, 1891, p. 22.

HUTH, Hans. "Impressionism Comes to America." Gazette des Beaux-Arts, Jan-June 1946, vol. XXIX, p. 225-256. 
IRWIN, Will, Earl C. MAY, and Joseph HOTCHKISS. A History of the Union League Club of New York City. New York: Dodd, Mead \& Company, 1952.

"Italian, Spanish, Dutch, English and French Paintings from the Collection of Catholina Lambert, Esq." Exhibition catalogue. The Union League Club. New York (NY), April 10-13, 1893. New York: The Union League Club, 1903.

MEIXNER, Laura L. French Realist Painting and the Critique of the American Society, 1865-1900. Cambridge: Cambridge University Press, 1995.

MILLER, Lillian B. Patrons and Patriotism, The Encouragement of the Fine Arts in the United States, 1790-1860. Chicago: The University of Chicago Press, 1966.

MILLS, C. Wright. “The Power Elite.” The Power Elite. London: Oxford University Press, 1956, p. 269-298.

MONTEZUMA. “My Note Book.” The Art Amateur, January 1886, p. 28.

---. “My Note Book.” The Art Amateur, March 1891, p. 88.

MOORE, Charlotte E. Art as Text, War as Context: The Art Gallery of the Metropolitan Fair, New York City's Artistic Community and the Civil War. 2009. Boston University. PhD dissertation

MORGAN, Howard W. New Muses, Art in American Culture, 1865-1920. Norman: University of Oklahoma Press, 1978.

MOTT, Frank L. A History of American Magazines, 1885-1905, vol. 2, Cambridge: Harvard University Press, 1957.

“New York Gossip: An Interesting Chapter on Club-Life." Chicago Daily Tribune, March 5, 1876, p. 5.

"Note." Annual Report of the Trustees of the Metropolitan Museum of Art, vol. 1, no. 1, 1871, p. 1-2.

OTT, John. "How New York Stole the Luxury Art Market." Winterthur Portfolio, vol. 42, no 2/3, 2008, p. 133-158.

"Paintings at the Union League Club." The Critic, February 21, 1891, p. 101.

"Pictures at the Union League." New York Times, February 13, 1891, p. 4.

"Picture Shows at Clubs." New York Times, January 30, 1887, p. 7.

POONTON, James. “The Union League Club.” New York Times, March 28, 1897, SM11.

PYNE, Kathleen. Art and Higher Life. Painting and Evolutionary Thought in Late Nineteenth Century America. Austin: University of Texas Press, 1996.

RIORDAN, Roger. “The Impressionist Exhibition.” The Art Amateur, May 14, 1886, p. 21.

SKALET, Linda H. The Market for American Painting in New York, 1870-1915. 1980. Johns Hopkins University. PhD dissertation.

SMITH, Marc S. Spéculation, marché de l'art et naissance d'un réseau artistique moderne aux États-Unis de l'industrialisation à la crise des années 1930. Un Monopole social et culturel en construction. 2011. Université Montpellier 3. PhD dissertation.

THOMPSON, Jennifer A. “Paul Durand-Ruel et l'Amérique.” Paul Durand-Ruel, Le Pari de l'impressionnisme. Ed. Sylvie PATRY. Paris: Réunion des musées nationaux, 2015, p. 107-120.

“The Fine Arts: The Loan Collection at the Fine Arts Building.” The Critic, Feb. 18, 1893, p. 103.

“The French Impressionists.” The Critic, April 17, 1886, p. 196. 
“The Paintings of the Impressionists." Washington Post, April 11, 1886, p. 4.

“The Union League Club Exhibition.” The Art Amateur, March 1891, p. 89.

The Union League Club of New York. New York: The Knickerbocker Press, 1891.

TOMKINS, Calvin. Merchants and Masterpieces: The Story of the Metropolitan Museum of Art. New York: Henry Holt \& Company, 1989.

TRUMBLE, Alfred. “Impressionists and Imitators.” The Collector, November 1889, p. 11

VAN OOST, John W. "My Note Book." The Art Amateur, Dec. 1902, no. 2, p. 2-5.

VOTTERO, Michaël. “To Collect and Conquer: American Collections in the Gilded Age.”

Transatlantica, no.1| 2013, transatlantica.revues.org/6492. Accessed 30 Nov. 2018.

WALKER, Sophia A. "Fine Arts: Art Culture Through Clubs and Libraries." The Independent, July 30, 1896, p. 7.

WARD, Susan H. "Fine Arts: The Loan Exhibition of the American Fine Arts Society." The

Independent, March 9, 1893, p. 7.

WHITE, Harrison, and Cynthia A. WHITE. Canvases and Careers: Institutional Change in the French Painting World. Chicago: University of Chicago Press, 1993.

WEITZENHOFFER, Frances. The Havemeyers: Impressionism Comes to America. New York: H.N. Abrams,1986.

ZAFRAN, Eric M. "Monet in America." Claude Monet (1840-1926) - A Tribute to Daniel Wildenstein and Katia Granoff. Ed. Guy WILDENSETEIN. New York: Wildenstein \& Co., Inc., 2007, p. 80-152.

\section{NOTES}

1. Exhibits at the Union League Club have never been thoroughly examined even if they have been mentioned in scholarly work. See for example: Brennecke 240; Dawson, 1996, 23; Huth, 1946, 246; Meixner 241; Weitzenhoffer 82-84; Zafran 94

2. Several press articles in the 1880s and early 1890s highlight the general ambivalence towards the movement (Riordan 21; Garczynski 592-595; Hart 22)

3. Showing pieces from one's collection at such a venue could reinforce the collector's status as well, yet some collectors did not always flaunt their Impressionist pieces in loan collections. For example, Catholina Lambert omitted his Impressionist pieces from the exhibition Italian, Spanish, Dutch, English and French Paintings from the Collection of Catholina Lambert, Esq at the Union League Club in 1903 (Italian, Spanish..., 1903). This omission highlights the still debated status of Impressionist pieces at the time.

4. The Union League Club was in fact one of the most political institutions to host Impressionist pieces early on. At the turn of the twentieth century, most French Impressionist paintings were included in World Fairs, gallery shows, Industrial Fairs, Art Association Exhibits. 


\section{ABSTRACTS}

Americans became acquainted with French Impressionism in the last decades of the nineteenth century. Surprisingly, private clubs were some of the first to endorse the movement, hosting impressionist exhibitions early on in the movement's arrival to the United States. Using New York's Union League Club as a case study, this article highlights the motivations and impact, both aesthetic and political, of the club's approval of Impressionism. Not only did impressionist art become a way for club members to assert their advanced taste in art, but the Union League Club's early praise of Impressionism, this essay argues, was key to the country's reception of the movement.

Les Américains découvrent l'Impressionnisme français dans les dernières décennies du XIXème siècle. Étonnamment, les clubs privés sont parmi les premiers à appuyer ce courant esthétique, accueillant, par exemple, des expositions dès l'arrivée de l'Impressionnisme aux États-Unis. Cet essai vise à mettre en lumière les motivations et l'impact, esthétique et politique, de l'adoption de l'Impressionnisme dans les «clubs » et s'appuie, pour ce faire, sur une étude de cas, celui de l'Union League Club de New York. Non seulement l'Impressionnisme permit aux membres du club d'affirmer leur goût «avancé » en art, mais l'approbation précoce du Union League club a joué un rôle clé dans la réception nationale du mouvement.

\section{INDEX}

Subjects: Hors-thème

Keywords: painting, art history, Gilded Age, transnational circulations, Gentlemen's clubs, Impressionism, history of taste

Mots-clés: peinture, histoire de l'art, Âge doré, circulations transnationales, clubs privés, Impressionnisme, histoire du goût

\section{AUTHOR}

\section{CLAIRE HENDREN}

Université Paris Nanterre

claire.hendren@gmail.com 